\title{
The Role of MGMP Civic Education in Improving Professional Competence of Teacher
}

Arifin

Universitas Muhammadiyah Kupang, Indonesia

Corresponding Author: Arifin, $\otimes$ rifilatihan@yahoo.com

\begin{tabular}{|c|c|}
\hline \multirow[b]{2}{*}{$\begin{array}{l}\text { ARTICLE INFO } \\
\text { Article history: } \\
\text { Received } \\
20 \text { October } 2019 \\
\text { Revised } \\
2 \text { December } 2019 \\
\text { Accepted } \\
30 \text { Desember } 2019\end{array}$} & ABSTRACT \\
\hline & $\begin{array}{l}\text { This study aimed to describe the role of Musyawarah Guru Mata Pelajaran } \\
\text { (MGMP) Civic Education in Malang City in enhancing the professional } \\
\text { competence of teachers and to know the efforts in Increasing the } \\
\text { professional competence of teachers. The researcher used qualitative } \\
\text { descriptive method. Data collection techniques used observation, } \\
\text { interview, and documentation. The results showed that the teachers of } \\
\text { Musyawarah Guru Mata Pelajaran (MGMP) Civic Education played an } \\
\text { active role in helping teachers to improve their professional competence. } \\
\text { The effort in increasing the professional competence of teachers namely, } \\
\text { conducts a seminar by inviting competent speakers. }\end{array}$ \\
\hline & Keywords: MGMP, Civic Education, Professional Competence of Teacher \\
\hline How to cite & $\begin{array}{l}\text { Arifin. (2019). The Role of MGMP Civic Education in Improving Professional } \\
\text { Competence of Teacher. Jurnal Iqra' : Kajian Ilmu Pendidikan, 4(2). 249-264. } \\
\text { https://doi.org/10.25217/ji.v4i2.557 }\end{array}$ \\
\hline Journal Homepage & $\begin{array}{l}\text { http://journal.iaimnumetrolampung.ac.id/index.php/ji/ } \\
\text { icle under the CC BY SA license } \\
\text { https://creativecommons.org/licenses/by-sa/4.0/ }\end{array}$ \\
\hline
\end{tabular}

\section{INTRODUCTION}

The teacher is a professional educator, as a professional educator, the teacher is not only required to carry out his duties professionally but also must have professional abilities. The ability that must be possessed by teachers include; pedagogical competence, professional competence, social competence, and personal competence (Husna, 2016; Bakar, 2018) ,in addition to the ability to manage teaching and learning processes which include the ability to prepare learning, the ability to carry out learning, the ability to manage classes, is able to use media, technology, teaching resources, and the ability to evaluate learning (Cirocki \& Farrell, 2019; Arifin, 2012; Prestridge, 2019). Teachers must always be innovative in developing their abilities thus in delivering learning material in accordance with current developments in science and technology (Owen, 2015). Improving the quality of education is an urgent need that must be done and seriously addressed. It can be reached by evaluating learning activities and evaluating teacher teaching. While also seeking quality education in accordance with the development of science and technology (Byers, Imms, \& HartnellYoung, 2018; Dong, Wang, Han, \& Zhang, 2019; Vongkulluksn, Xie, \& Bowman, 
2018). Thus, expect students to be ready to continue to higher education as well as prospective skill workers and expert workers. One way to improve the quality of education was by increasing the quality and ability of teachers.

Law of Republic Indonesia number 14 of 2005 concerning Teachers and Lecturers, requires teachers (i): to possess a minimum academic qualification of Master or Diploma; (ii); has competence as an agent of learning, namely pedagogic, personality, social, and professional competencies; and (iii) have an educator certificate (Depdiknas, 2005). With the enactment of this Act, it was expected to provide an appropriate opportunity for teachers to improve their professionalism through training, scientific writing, meetings in Teacher Kelompok Kerja Guru (KKG), and sessions in the Guru Mata Pelajaran (MGMP). Thus MGMP has an essential role in supporting the professional development of teachers. Teacher Subject Discussion, which is then called MGMP as a forum for teachers to improve their abilities and competencies to be better prepared in facing various learning difficulties (Emiliasari, 2018; Husna, 2016). MGMP has a significant position to improve teacher understanding in the whole learning process (Purwoko, Andayani, Muntar, \& Diartha, 2017), especially with the replacement of the Kurikulum Tingkat Satuan Pendidikan (KTSP) curriculum with the K13 curriculum. Although MGMP was not the only determinant of expected quality, MGMP was needed as a means of communication for teachers to improve their professionalism. Some indicators of the role of MGMP according to Abdillah, Pramita, Habib (2018) concerning to enhance teacher professional competence include the role of MGMP as; learning reformer; mediator in the development and improvement of teacher competencies, supporting agencies in classroom management and school management, collaborators with relevant units and relevant professional organizations, evaluators, and as clinical and academic supervisors.

At present, almost all class teachers, as well as study subject teachers in regencies and cities, agree to establish and participate in KKG or MGMP. The organization has been running and has programs. In the increasingly rapid development, teachers have realized that self-development and knowledge insight was very necessary as a provision to carry out their duties (Goldie, 2016; Jacob, Hill, \& Corey, 2017). Hopefully, the quality of teachers in the City will be no different from those in corner areas. The MGMP Civic Education was under the auspices of the Youth and Sports Education Office of the Malang City Government. The MGMP activity center was in State Junior High School 2 Malang, with 115 teachers as members. The problems found that the schools that incorporated in the MGMP Civic Education were spread of throughout the Malang City. For some teachers, MGMP activity was very helpful. Still, some 
other teachers consider that the MGMP activity was a classic activity, only gathering to meet friends without gave an impact results and motivation, did not care the importance of insight and knowledge to improve competency in becoming professional teachers (Widayati, 2013). The improvement of competency professional teacher can be done in various ways such as further education in the office, the establishment of forums for improving the quality of teachers such as fostering Penilaian Kinerja Guru (PKG), Kelompok Kejra Guru (KKG), Musyawarah Penilaian Kinerja Guru, and so forth. But the activities that have not been packaged in a professional manner. So it is not surprising that every time a teacher finishes attending MGMP and other upgrading courses, it seems that there was no change in the teaching-learning process (Husna, 2016). Through MGMP activities, teachers will be able to improve their abilities in the learning process. All forms of difficulties encountered in the field easily find a solution from MGMP teacher participants (Hayati, 2016). According to Anwar (2011), In carrying out its functions, the teacher did not act alone but must interact with other teachers involved through an atmosphere of partnership that was systematic, synergistic, and symbiotic. Likewise, interdisciplinary disciplines should interact and collaborate in facing various problems that arise. An interdisciplinary approach in the form of a work team was absolute and must be used as a basis for teacher performance. Problems above intimate that MGMP activities in the field were not in line with what was expected. MGMP was more interpreted as an ordinary organization as a gathering place for teachers per subject only. Therefore teachers provided by the government to teach in public schools, especially in Malang City Junior High Schools, need to have the professionalism and good teaching performance in their service to direct students to better ones. It was expected that professionalism and teaching performance was owned by teachers who teach in public schools, there was a place for teacher discussion (MGMP) including teacher deliberations per subject that has objectives as stated by Nurlaeli \& Saryono (2018) that the effectiveness of MGMP can improve the professionalism and performance of teachers, with the existence of MGMP activities all teachers can improve their performance in carrying out their duties as educators and can unite perceptions with teachers of similar subjects.

Numerous previous studies related to teachers in MGMP in developing competence. Emiliasari (2018) reported that teachers have a good understanding and implementing of pedagogical competence. It's mean that the teachers can manage the classroom management, curriculum development, understanding the students' characters and teacher's talk. Furthermore, Firman (2016) studied about MGMP in Improving the Performance of Teachers 
in Islamic Education in High Schools in the City. This study was reported that MGMP was an effective forum for subject teachers in developing learning tools, making teaching materials, methods, and learning models based on the school environment. Salirawati \& Subali (2016) reported that through MGMP IPA teachers were able to design the ideational evaluation worksheet, obtained from the performance of the designing task book evaluation. Furthermore, Sitisyarah \& Aisyah (2019) on her research found there is significant positive relationship between teachers' participation in MGMP and the performance of Mathematics teachers. Different from this present study which emphasizes in describing the role of the Musyawarah Guru Mata Pelajaran (MGMP), especially in of Civic Education in developing the professional competence of teachers, in order to know the efforts made by the deliberations of teachers in increasing professional teacher competence. The researcher also more comprehensive in analysing of the role of the Musyawarah Guru Mata Pelajaran (MGMP) as learning effective reformer, mediator, supporting agency, collaborator, evaluator, and supervisor.

This research was important to do in which MGMP as a forum and not only to improve teacher competency professionally, but also as a learning reformer, and as a mediator in developing teacher competency. The MGMP which is in State Senior High School Malang was an independent MGMP, because the activity funds come from the contributions of the members, and a small portion comes from the government. Although the MGMP has limited funds, due to the persistence of the management and awareness of the members, this MGMP still contributes to the development of teacher competencies. From the description above, the aim of this study was to describe the role of Musyawarah Guru Mata Pelajaran (MGMP) Civic Education in Malang City in enhancing the professional competence of teachers and to know the efforts Civic MGMP in increasing the professional competence of teachers.

\section{RESEARCH METHODOLOGY}

This study uses a descriptive qualitative method because this study seeks to describe and analyze phenomena, events, social activities, attitudes, and perceptions of a person or group (Setiawan, 2018; Killam \& Heerschap, 2013; Conway, 2014). Techniques collection data used observation, interviews, and documentation. The observation technique was used to observe the activities (activities) MGMP associated to training, provided to teachers and regular meetings of members.

Interview technique was used to obtain data on the role of MGMP as a reformer, mediator, supporting Agency, collaborator, evaluator, clinical, and 
academic supervisor. The sample of interview involve Drs. Masduqi (Head of Civic Musyawarah Guru Mata Pelajaran (MGMP), and some member of Musyawarah Guru Mata Pelajaran (MGMP), for instance Riyanto, S.Pd, Drs. Hariono, Dra. Setianingsih, and Dra Sri Handayani. Furthermore, Technique documentation was used to obtain MGMP role data, Materials in Seminar, from various MGMP documents and work programs, material that has been submitted, photos of events conducted by Malang City on MGMP Civic Education. The expected documentation data can be obtained from the Malang City Education Office and MGMP studio which contains data on teacher profiles, the number of Civics teachers, MGMP work programs, etc.

The data used in this study consisted of two sources, namely primary data and secondary data. Primary data was data directly obtained from core informants; those are the Malang City Education Office, Head of MGMP, and MGMP members. Secondary data collected in the form of written manuscripts or documents related to this research. The researcher used triangulation techniques. To test the validity of the data. And to get the data analysis techniques used Milles model interaction techniques that include data collection, data reduction, data presentation, and concluding.

\section{RESEARCH RESULTS AND DISCUSSION}

\section{The Role of MGMP Civic Education as an Effective Learning Reformator}

As an effective learning reformer, MGMP has the function of formulating various learning models and teaching aids or learning practices, including lifeskill learning models. Effective learning was a student-centered teaching and learning process. Students actively work and work while the teacher guides and directs. According to Kyriacou in (Setyosari, 2017) included two main things, namely "active learning time" and quality of learning "quality of instruction". The first thing concerns the amount of time devoted to students during the lesson. How students engage in learning process to achieve the expected goals. The second thing has to do with the actual quality of learning itself. Thus effective learning cannot be separated from learning quality. Learning quality can only be realized by qualified teachers to create a quality classroom atmosphere (Blankson \& Blair, 2016).

In collecting data in interview, Masduqi explained that many factors need to be considered in realizing quality classrooms, among others, namely: first, the learning approach should be oriented to how the students learn (student-centered). Second, there was teacher appreciation for the active participation of students in each learning context. Third, teachers should be democratic in managing learning activities (Masduqi, Head of MGMP Civic

\section{3}


Education, 2019, May 20). Fourth, any problems that arise in the learning process should be discussed dialogically. Fifth, the classroom environment should be set up in such a way as to motivate student learning and encourage the learning process. Sixth, provide various types of learning resources or information related to various learning resources that can be accessed quickly by students.

Based on the above study, as a reformer of MGMP Civic Education at Malang City tried to provide useful activities such as the development of teaching materials, the use of media, how to use learning methods and to evaluate the teaching and learning process. MGMP provided input in the form of a large concept through the provision of seminars and workshops or at regular meetings, after which teachers are invited to develop what they get in different ways. MGMP activities are really needed by members, especially activities related to effective learning. Effective learning was required by MGMP members, namely (a) encourage students to play an active role in learning, (b) develop students' skills, (c) provide opportunities for students to express their own ideas verbally and in writing, (d) adjust teaching materials and learning activities with the ability of students, and (e) linking teaching and learning activities to students' daily experiences.

\section{The Role of MGMP Civic Education as a Mediator}

As a mediator, MGMP initiated the preparation of appropriate learning programs (ranging from understanding the curriculum, preparing lesson plans, ,Prota, Promes, etc., to the stage of assessment and evaluation of learning in the classroom, and as a medium for the development of knowledge for members including as a medium for obtaining information on developments Civic learning in particular and the development of education. Thus, it can be understood that as a mediator, MGMP has a role in developing and improving teacher competencies, especially through curriculum development.

"In general, MGMP members recognize the important role of MGMP as a mediator. His role in initiating the preparation of work programs, arranging schedules and places of activities on a regular basis, as well as providing educational, technical information relating to scientific activities, development of science and technology, curriculum implementation" (Riyanto, Member of MGMP Civic Education, 2019, June 22). All of these are felt by members to be very helpful in expanding their scientific "horizons. But in reality, as a mediator, MGMP is only a medium for the delivery of information for members, the distribution of aspirations, and the exchange of experiences. During regular meetings, the members complement each other. Whereas at the

\section{4}


stage of drafting prota, promes notes, and lesson plans were not given, because of the activities and tasks of the teacher that have been done every day. It was revealed by the MGMP coordinator that the preparation of lesson plans, prota, promes was the main task of the teacher, so we believe our teachers are able to do that. Analyzing the statement, it was not a matter of trust or disbelief of the leadership of the members, but rather on the demands of how the leader develops the function to make it effective, helpful, direct, motivate, and even know where the members' weaknesses are. The point is as a medium for obtaining and disseminating MGMP information is a strategic place, but as a direct liaison media in order to train members to develop learning tools has not been done, only entrusted with the belief that each member can do that. However, if an intensive approach was not taken, members tend to commit fraud, for example, not carrying lesson plans when teaching.

\section{The Role of MGMP Civic Education as a Supporting Agency}

Supporting Agency was a supporter, both in the form of financial, thought, and energy, in the administration of education in schools (Sunaryo \& Chamisijatin, 2009). Supporting Agency, in this case, was a form of support provided by MGMP as an organizational implementer of teachers in order to help teachers to continue to improve their abilities and services to students.

The indicators of the supporting Agency were motivating teachers to be active in MGMP activities and fostering teachers in improving teaching and learning activities. The amount of activity that was owned by each member starting from preparing the learning implementation plan, to the other activities that prevent the members from being able to attend the MGMP activities. To overcome these problems, the MGMP did a lot of things starting from the preparation of a pleasant agenda. It always involving members in its operations, making urgent programs, conducting seminars to improve the ability of teachers, knowing the needs of members, and implementing a fair attitude towards all members. the MGMP provide opportunities for members to attend seminars from outside. It as the supporting efforts for members to always hone their abilities, at each member school get transport money to come to the MGMP meeting place, deliver urgent materials, involve members in each of their activities. MGMP were also being made to involve members in promoting programs that will be prepared through joint discussions, conducting comparative study activities, as well as inviting speakers related to the deepening of the material.

As a government partner, the MGMP feels that it has a responsibility to provide encouragement and input directly to members. Besides that, the 
MGMP was a very effective medium for conducting discussions and deliberations between teachers. So that close relationships can be established. More importantly, the teacher was given the opportunity to express his wishes and "feelings" directly; besides that, members feel involved in encouraging school progress. MGMP was expected not only to provide support as described above but in all the components of what is done by the teacher, MGMP must always support it.

It was necessary to strengthen the preparation of proportional agenda and in accordance with the needs of teachers, presenting urgent material, to motivate teachers to take part in MGMP activities. So that teachers would be called to be active in MGMP activities because in addition to providing benefits for enhancing their professional abilities. It was also a forum filtering aspirations for teachers in responding to various changes in education (teaching and learning).

\section{The Role of MGMP Civic Education as a Collaborator}

The role of MGMP as a collaborator has the indicator to spread the results of cooperation that obtained workshops, training, and discussing. Teachers' professional capacity building activities were not only carried out at the studio level by each MGMP but also at higher levels through collaboration with universities.

Figure 1. Workshop of MGMP Civic Education

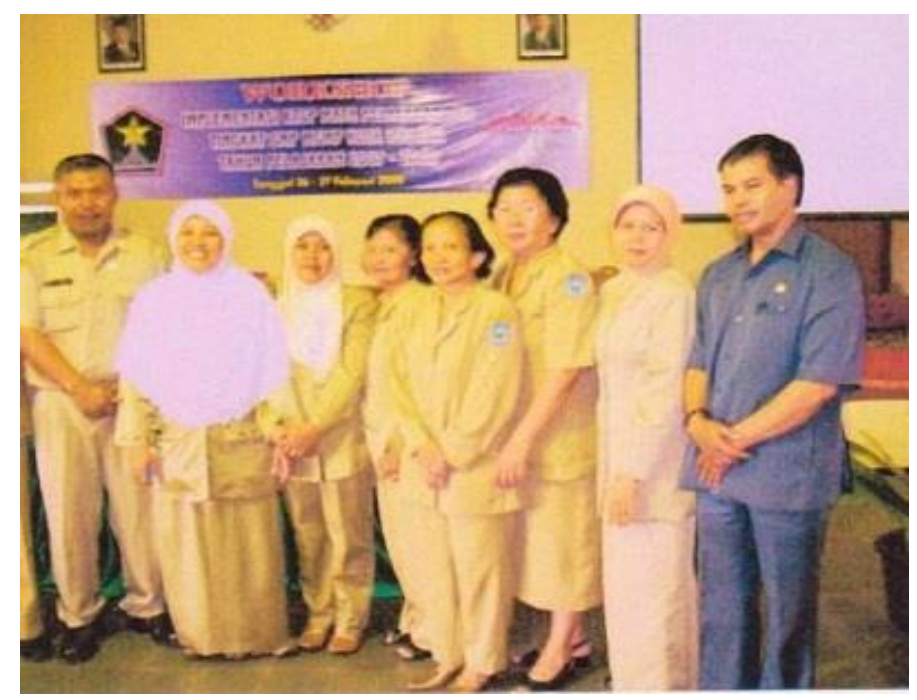

Figure 1 explained that MGMP Civic Education as a collaborator always cooperates with other stake holder, like University or Schools in Malang. It was done to support the performance of its members. In addition, each member who has conducted or participated in seminars, workshops, was obliged to deliver or disseminate to other members through regular meetings or on a 
predetermined agenda. As well as providing suggestions to the teacher. Through MGMP, all the members can share to each other about what they have gained and exchange ideas both in the form of learning models (the development of Civics learning), using the learning media, policies at the official and national levels so that members can solve problems together. A harmonious relationship between members and leaders, members, and members, as well as all school components, must be an organizational priority. Thus the goals in an organization can be achieved.

In general, the members of the MGMP Civic Education of State Junior High School at Malang City realize the importance of MGMP's role as a collaborator. By actively collaborating with fellow MGMPs, collaborating with schools to disseminate the results of upgrading at the workshop, working together with universities to develop material and competencies would increase the excitement of teachers in preparing and evaluating teaching and learning programs.

\section{The Role of MGMP Civic Education as an Evaluator}

The purpose of the MGMP as an evaluator is to evaluate the performance of the organization by discussing, developing suggestions and reporting the results of these activities to the education office.

Figure 2. Meeting in Socialization MGMP

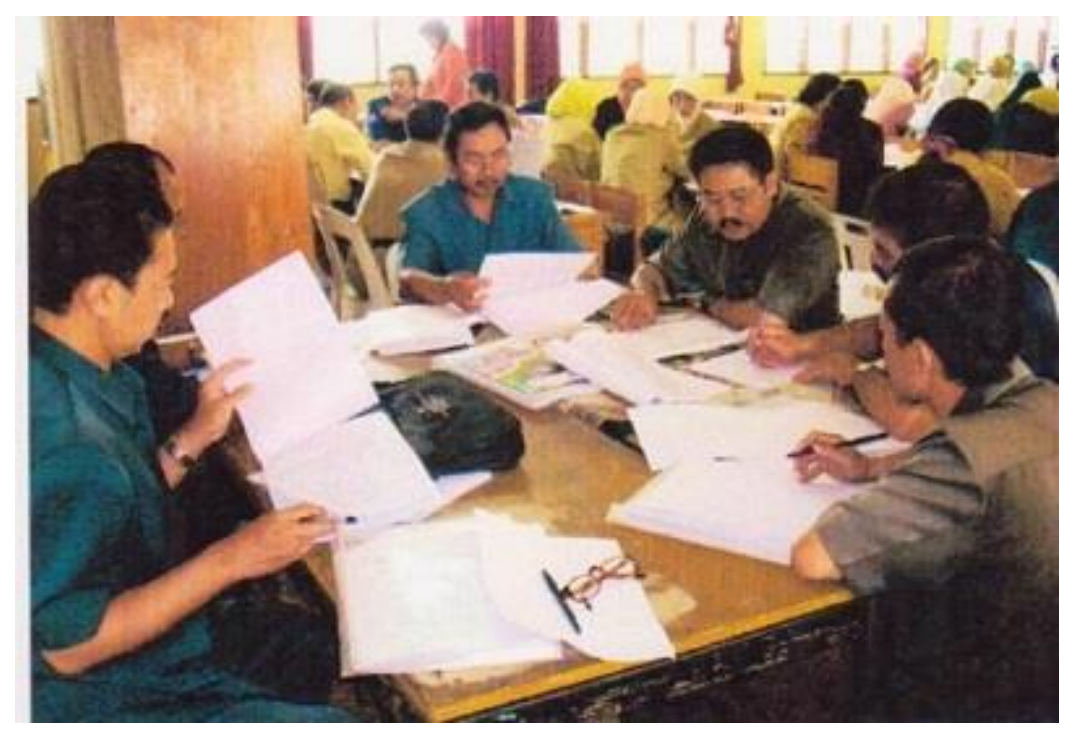

Figure 2 explored that some Teachers' MGMP Civic Education done gathering (meeting) in evaluating MGMP. To improve performance evaluation, the role of the MGMP as an evaluator is felt to be very necessary to accommodate or discuss suggestions and opinions that develop in schools, 
studios, offices, regularly report the results of activities every semester to the principal or coordinator and the department. MGMP provides a lot of information to teachers about the developmen in learning and educational policies. These policies can be conveyed through regular discussions or meetings conducted by members. Teacher professional capacity building activities were not only held at the studio level by each MGMP but also at higher levels through a partnership with universities. Although it was realized how important as described above. the role of the MGMP as an evaluator had not been carried out to the full extent as conveyed by the MGMP coordinator, that they did not evaluate the extent of their members' abilities but oprovided motivation to improve their abilities continually. Even though evaluation was the most crucial stage to do, by evaluating the leadership continuously, it can find out the progress and weaknesses of the members.

\section{The Role of MGMP Civic Education as Clinical and Academic Supervisors}

Clinical and Academic Supervisor MGMP has the purpose of making clinical or academic supervision services to obtain effective learning. Active, creative, innovative, and effective active learning was the desire of all educational institutions so that efforts to improve the ability of teachers become a priority. MGMP in streamlining learning activities to provide clinical supervision services to members. The results showed that the supervision efforts undertaken by MGMP were through research and peer teaching programs as well as collaborating with LPMP or the University. Supervision activities carried out in order to assist teachers in improving the learning process based on the findings of teacher weaknesses in learning. This supervision activity was carried out by the coordinator, chairperson, colleague, and school supervisor in order to obtain flexibility in finding various expected solutions.

\section{The Efforts of MGMP Civic Education in Increasing the Professional Competence the Teachers}

The efforts made by MGMP in overcoming these obstacles include; conduct a seminar, to improve teacher professional competence by inviting competent speakers; making useful roles for the MGMP, because efforts to improve teacher professional competence have been set out in the form of the role that the MGMP entails which was realized in the form of seminars, workshops, assessment materials, writing textbooks. It was necessary to optimize the support of all stakeholders, optimizing the workgroup of school principals). Every obstacle faced needs to be addressed wisely and wisely, the 
more obstacles that were passed indicate, the more effective efforts made so that many programs are realized. This requires the ability of the board to do many things in overcome problems that occur.

The main finding of this research was Musyawarah Guru Mata Pelajaran (MGMP) Civic Education of State Junior High School at Malang city has an active role in improving teacher professional competence that was manifested in the mastery learning and quality teachers in teaching and learning activities. Moreover, they have high integrity in carrying out their duties as learning effective reformer, mediator, supporting agency, collaborator, evaluator, and supervisor. Thus, it was understood by most of teacher Civic Education at Malang, MGMP Civic Education place of in developing education. Because the teachers can give input to each other what they have obtained and exchange the ideas either in the form of learning models (the development of Civics learning), the right media, policies at the service level and the national level. Thus, the members can solve problems together. The finding was different from result research Widayati (2013) who explained that MGMP activities were classic activities, only gathering to meet friends without bringing results, not based on high motivation on the importance of insight and knowledge to improve competence to become professional teachers. While, Abdullah (2018) suggested that MGMP focused on increasing of teachers' competency in making RPP. Kadir (2018) also explored that Islamic Education MGMP can improve the teachers' creativity in teaching to achieve ideal standard after giving a training assure model. Those finding were also different of the current research. Because the current research was more comprehensive that declared the role of MGMP Civic Education as as learning effective reformer, mediator, supporting agency, collaborator, evaluator, and supervisor clearly. As reformer, has a role in improving teacher professional competence by providing useful activities such as the development of teaching materials, media use, how to use learning methods, and evaluating teaching and learning processes. As a mediator has a role in initiating work program preparation, arranging schedules and places of activities on a regular basis, development of science and technology, curriculum implementation. As a Supporting Agency, is needed in an effort to motivate its members to improve their abilities and skills as collaborator: disseminate the results of upgrading at seminar or workshop, etc. Musyawarah Guru Mata Pelajaran (MGMP) activities, all teachers can improve their performance in carrying out their duties as educators and can unite perceptions with teachers of similar subjects (Nurlaeli \& Saryono, 2018). MGMP was an effective forum for subject teachers in developing learning tools, making teaching materials, methods, and learning models based on the 
respective school environment (Firman, 2016). While, Anwar (2011) said all forms of difficulties encountered in the field would be easy to find a solution from MGMP participant teachers.

The researcher also found the implication of this research. The research has shown that the role of Musyawarah Guru Mata Pelajaran (MGMP) Civic Education was very important in order to improve the professional competence of Teachers' Civics Education State Senior High School 1 Malang. MGMP was a very effective forum for teacher in self-development in learning. The implications, involve: (1) implications for planning and developing the role of the MGMP; (2) implications for self-development and improvement in the quality of teachers; (3) implications for the teacher's perspective on the MGMP container; and (4) implications for the important role of MGMP in formulating, developing, and realizing competent educators in accordance with national education standards with MGMP as the main pillar.

\section{CONCLUSION}

Based on the results of research and discussion can be concluded as that The role of the MGMP Civic Education as an effective learning reformer. As a reformer, Musyawarah Guru Mata Pelajaran (MGMP) Civic Education has a role in improving teacher professional competence by providing useful activities such as the development of teaching materials, media use, how to use learning methods, and evaluating teaching and learning processes. As a mediator, MGMP has a role in initiating work program preparation, arranging schedules and places of activities on a regular basis, development of science and technology, curriculum implementation. As a Supporting Agency, is needed in an effort to motivate its members to improve their abilities and skills. The form of MGMP's role in motivating members includes: by involving members in submitting programs that will be prepared through a questionnaire or discussion at the beginning of the school year, conducting comparative study activities, inviting resource persons related to the deepening of the material. The role of the MGMP as a collaborator: Active collaboration between existing MGMPs, collaboration with schools to disseminate the results of upgrading at seminar or workshop, do collaboration to developt of pedagogic material and competencies. The role of the MGMP as an evaluator was felt to be very necessary to accommodate or discuss suggestions and. The role of Supervision activities carried out in order to assist teachers in enhancing the learning process based on the findings of teacher weaknesses in learning. Then the efforts in increasing the professional competence of the teachers involve conduct a seminar to improve teacher professional competence by inviting 
competent speakers, doing workshops, LKS preparation and writing textbooks, optimizing K3S support (kelompok kerja kepala sekolah)

The suggestion of this research that the government (Department of Education and Culture) of Malang City encourage the optimization of the role of the MGMP with the MGMP empowerment program, MGMP administrators and members always be serious in providing support to teachers to improve their competence, To improve their professional competence, teachers were advised to participate fully in the programs implemented by MGMP. so that they were behave professionally towards their duties and responsibilities as educators, instructors, supervisors, assessors and evaluators.

\section{ACKNOWLEDGMENTS}

The authors would like thank Sri Wahyuningtyas, M.Si as the Head of Department of Education and Culture of Malang City and deep appreciation to Drs. Masduqi as Head of MGMP Civic Education Malang city who has given motivation to author to immediately complete this research. Thank you also expressed to the Member of MGMP Civic Education Malang city who has given motivation to the authors to complete this research.

\section{AUTHOR CONTRIBUTION STATEMENTS}

The author had participated in the research and approved the final version of the manuscript.

\section{REFERENCES}

Abdullah, R. (2018). Meningkatkan Kompetensi guru dalam penyusunan RPP Yang Baik Dan Benar Melalui Pendampingan Berbasis MGMP Semester ganjil Tahun Pelajaran 2017/2018 SMP Negeri 1 Ambalawi. Jurnal Ilmiah Mandala Education (JIME), 4(1), 67-78.

http:/ / dx.doi.org/10.36312/jime.v4i1.327

Abdillah, A., Pramita, D., \& Habib, R. P. N. (2018). Peningkatan Global Media and Information Literacy Professional Network (GMILPN) MGMP Matematika di NTB. JPMB: Jurnal Pemberdayaan Masyarakat Berkarakter, 1(1), 01-09. Google Scholar

Anwar, R. (2011). Pengaruh Musyawarah Guru Mata Pelajaran (MGMP) Terhadap Peningkatan Profesionalisme Dan Kinerja Mengajar Guru SMA Negeri Kota Tasikmalaya. Jurnal Administrasi Pendidikan, 13(1). Google Scholar 
Arifin. (2012). Peran Musyawarah Guru Mata Pelajaran (MGMP) Pendidikan Kewarganegaraan Kota Malang Dalam Meningkatkan Kompetensi Profesional Guru (Other, University of Muhammadiyah Malang).Google Scholar

Bakar, R. (2018). The influence of professional teachers on Padang vocational school students' achievement. Kasetsart Journal of Social Sciences, 39(1), 67-72. https:/ / doi.org/10.1016/j.kjss.2017.12.017

Byers, T., Imms, W., \& Hartnell-Young, E. (2018). Evaluating teacher and student spatial transition from a traditional classroom to an innovative learning environment. Studies in Educational Evaluation, 58, 156-166. https:// doi.org/10.1016/j.stueduc.2018.07.004

Blankson, A. N., \& Blair, C. (2016). Cognition and classroom quality as predictors of math achievement in the kindergarten year. Learning and Instruction, 41, 32-40. https:/ / doi.org/10.1016/j.learninstruc.2015.09.004

Cirocki, A., \& Farrell, T. S. C. (2019). Professional development of secondary school EFL teachers: Voices from Indonesia. System, 85, 102111. https:/ / doi.org/10.1016/j.system.2019.102111

Conway, C. M. (2014). The Oxford Handbook of Qualitative Research in American Music Education. Oxford University Press. Google Scholar

Darling-Hammond, L. (2016). Research on Teaching and Teacher Education and Its Influences on Policy and Practice. Educational Researcher, 45(2), 83-91. https:/ / doi.org/10.3102/0013189X16639597

Depdiknas. (2005). tahun 2005 tentang Guru dan Dosen.

Dong, Q. W., Wang, S. M., Han, F. J., \& Zhang, R. D. (2019). Innovative Research and Practice of Teachers' Teaching Quality Evaluation under the Guidance of 'Innovation and Entrepreneurship.' 154(2), 770-776. https:/ / doi.org/10.1016/j.procs.2019.06.123

Emiliasari, R. N. (2018). An analysis of teachers' pedagogical competence In lesson study of MGMP SMP Majalengka. ELTIN Journal, 6(1), 22-32. https://doi.org/10.22460/eltin.v6i1.p22-33

Firman, F. (2016). Peranan MGMP Dalam Meningkatkan Kinerja Guru Mata Pelajaran Pendidikan Agama Islam SMA di Kota Balikpapan. JST (Jurnal Sains Terapan), 2(1). https:/ / doi.org/10.32487/jst.v2i1.113

Goldie, J. G. S. (2016). Connectivism: A knowledge learning theory for the digital age? Medical Teacher, 38(10), 1064-1069. https:// doi.org/10.3109/0142159X.2016.1173661

Hayati, E. (2016). Evaluasi model cipp terhadap program musyawarah guru mata pelajaran (MGMP) kimia Kota Padang. Ta'dib, 13(2). http:/ / dx.doi.org/10.31958/jt.v13i2.182 
Husna, F. (2016). Peran Musyawarah Guru Mata Pelajaran (Mgmp) Untuk Meningkatkan Kompetensi Profesional Guru PAI: Studi Kasus MGMP PAI SMP Negeri Kabupaten Kediri. Didaktika Religia, 4(2), 205-224. https:// doi.org/10.30762/ didaktika.v4.i2.p205-224.2016

Jacob, R., Hill, H., \& Corey, D. (2017). The Impact of a Professional Development Program on Teachers' Mathematical Knowledge for Teaching, Instruction, and Student Achievement. Journal of Research on Educational Effectiveness, 10(2), 379-407. https:// doi.org/10.1080/19345747.2016.1273411

Kadir, A. (2018). Peningkatan Kreativitas Guru Dalam Mengajar Melalui Pelatihan Model Assure Dengan Pendekatan Scientific Pada Mgmp Pendidikan Agama Islam Di Sekolah Menengah Atas Kabupaten Indragiri Hulu Tahun 2017. Akademika: Jurnal Keagamaan dan Pendidikan, 14(1), 1-19. Google Scholar

Killam, L. A., \& Heerschap, C. (2013). Challenges to student learning in the clinical setting: A qualitative descriptive study. Nurse Education Today, 33(6), 684-691. https:/ / doi.org/10.1016/j.nedt.2012.10.008

Masduqi. (May 20, 2019). The Result Interview, Head of Musyawarah Guru Mata Pelajaran (MGMP) Civic Education, at State Junior High School 2 Malang.

Nurlaeli, Y., \& Saryono, O. (2018). Efektivitas Musyawarah Guru Mata Pelajaran (MGMP) Dalam Meningkatkan Kinerja Mengajar Guru Bahasa Inggris. 2(2), 10. Google Scholar

Owen, S. M. (2015). Teacher professional learning communities in innovative contexts: 'ah hah moments', 'passion' and 'making a difference' for student learning. Professional Development in Education, 41(1), 57-74. https:/ / doi.org/10.1080/19415257.2013.869504

Prestridge, S. (2019). Categorising teachers' use of social media for their professional learning: A self-generating professional learning paradigm. Computers $\mathcal{E}$ Education, 129, 143-158. https://doi.org/10.1016/j.compedu.2018.11.003

Purwoko, A. A., Andayani, Y., Muntar, M., \& Diartha, I. N. (2017). Efforts in Improving Teachers' Competencies Through Collaboration between Teacher Forum on Subject Matter (MGMP) and Pre-Service Teacher Training Institution (LPTK). Jurnal Pendidikan IPA Indonesia, 6(1). https:// doi.org/10.15294/jpii.v6i1.8858

Riyanto. (June 22, 2019). The Result Interview, Member of Musyawarah Guru Mata Pelajaran (MGMP) Civic Education, at Junior High School 2 Wahid Hasyim. 
Salirawati, d., \& Subali, b. (2016). Ibm MGMP IPA smp kota yogyakarta dan kabupaten sleman dalam mengembangkan lkpd yang digunakan pada strategi pembelajaran untuk meningkatkan kreativitas peserta didik melalui pendekatan ideational learning. Inoteks, 20(2), 105-121. Google Sholar

Setyosari, P. (2017). Menciptakan Pembelajaran Yang Efektif Dan Berkualitas. JINOTEP (Jurnal Inovasi dan Teknologi Pembelajaran) Kajian dan Riset dalam Teknologi Pembelajaran, 20-30. https:/ / doi.org/10.17977/um031v1i12014p020

Setiawan, A. A., Johan. (2018). Metodologi penelitian kualitatif. CV Jejak (Jejak Publisher). Google Scholar

Sitisyarah, K., \& Aisyah, A. (2019). The Relationship of Transformational Leadership Style of Principals and Participation of Teachers in MGMP with Mathematics Teachers' Performance. Jurnal Dosen Universitas PGRI Palembang. Google Schoolar

Sunaryo, H., \& Chamisijatin, L. (2009). Pengembang Dan Strategi Pengembangan Kurikulum Sekolah. Google Scholar

Vongkulluksn, V. W., Xie, K., \& Bowman, M. A. (2018). The role of value on teachers' internalization of external barriers and externalization of personal beliefs for classroom technology integration. Computers $\mathcal{E}$ Education, 118, 70-81. https:// doi.org/10.1016/j.compedu.2017.11.009

Widayati, A. (2013). Studi Tentang Peran Musyawarah Guru Mata Pelajaran Akuntansi Dalam Meningkatkan Profesionalitas Guru Akuntansi SMK Di DIY. Jurnal Pendidikan Akuntansi Indonesia, 11(1). https:/ / doi.org/10.21831/jpai.v11i1.1677

Copyright Holder :

(c) Arifin. (2019).

First Publication Right :

(C) Jurnal Iqra' : Kajian Ilmu Pendidikan

This article is under:

() (1) (2) 